\title{
Influence of Burner Position on Temperature Distribution in Soybean Flaming
}

\author{
Miloš Rajković ${ }^{1, *(1)}$, Goran Malidža ${ }^{1}$, Strahinja Stepanović ${ }^{2}$, Marko Kostić ${ }^{3}$, \\ Kristina Petrović ${ }^{1}$ D, Mirko Urošević ${ }^{4}$ and Sava Vrbničanin ${ }^{4}$ \\ 1 Institute of Field and Vegetable Crops, Maksima Gorkog 30, 21000 Novi Sad, Serbia; \\ goran.malidza@ifvcns.ns.ac.rs (G.M.); kristina.petrovic@nsseme.com (K.P.) \\ 2 Henry J. Stumpf International Wheat Center, University of Nebraska, Grant, Nebraska 69140, USA; \\ strahinja.stepanovic@unl.edu \\ 3 Faculty of Agriculture, University of Novi Sad, Trg Dositeja Obradovića 8, 21000 Novi Sad, Serbia; \\ markok@polj.uns.ac.rs \\ 4 Faculty of Agriculture, University of Belgrade, Nemanjina 6, 11080 Belgrade, Serbia; \\ urom@agrif.bg.ac.rs (M.U.); sava@agrif.bg.ac.rs (S.V.) \\ * Correspondence: milos.rajkovic@nsseme.com; Tel.: +381 648706116
}

Received: 30 January 2020; Accepted: 10 March 2020; Published: 13 March 2020

\begin{abstract}
The main objective of this study was to identify optimal burner orientation for a newly designed flame cultivator by quantifying the flame temperature distributions of cross, back, and parallel position of burners at different heights of the soybean canopy (distance from the soil surface). Flame temperatures were measured within-row for three burner orientations at seven propane doses (20-100 kg/ha) and eight different canopy heights (0-18 cm above soil surface). Soybean plants in V3 growth stage were flamed with the same doses and burner orientations, and 28 days after treatment (DAT) crop injury (0\%-100\%), plant height (cm), dry matter $(\mathrm{g})$ and grain yield $(\mathrm{t} / \mathrm{ha})$ were assessed. All three burner orientations had high flame temperatures at lower canopy heights ( $<6 \mathrm{~cm}$ high) that gradually decreased with increasing canopy height $(6-18 \mathrm{~cm})$. Measured temperatures ranged from 33 to $234^{\circ} \mathrm{C}$ for cross flaming, 29 to $269{ }^{\circ} \mathrm{C}$ for back flaming and 23 to $155^{\circ} \mathrm{C}$ for parallel flaming, with high variability in temperature patterns. Back flaming generated flame temperatures above $100^{\circ} \mathrm{C}$ at a lower propane dose $(27 \mathrm{~kg} / \mathrm{ha})$ compared to cross and parallel flaming (40 and $50 \mathrm{~kg} / \mathrm{ha}$ ). For all tested parameters, parallel and cross flaming had better impact on soybeans than back flaming, but for weed control in crop rows, cross flaming is recommended.
\end{abstract}

Keywords: burner orientation; flame weeding; soybean; propane dose; temperature

\section{Introduction}

Weeds are one of the greatest limiting factors for an efficient crop production system and are economically more destructive than other pest organisms [1]. This is especially true in organic crops where the use of chemicals is prohibited [2]. Organic producers cite weed control as their foremost production-related problem [3] and have strong economic interests to protect crops from yield loss caused by weeds [4].

Cultural practices that row crop producers (e.g., maize, soybean, sunflower) typically use to manage weeds organically, such as crop rotation, delayed planting, or cultivar selection, are usually not efficient enough to control weeds below the economic threshold [5]. Therefore, weeds in organic production are largely managed with mechanical cultivation and/or hand weeding. Cultivation, however, is not efficient for weeds in rows, and hand weeding is often too expensive (e.g., ranging from 200 to 1200 USD/ha), time consuming, and difficult to organize [2]. Thus, there is an urgent need to evaluate alternative methods that could be utilized for weed control in organic cropping systems [2]. 
Flaming is one of the most promising alternatives for weed control in organic and conventional cropping systems, as it leaves no chemical residues in plants, soil, air or water, does not disrupt the soil surface (thus reducing the risk of soil erosion), does not bring buried weed seeds to the soil surface, and it is significantly cheaper than hand weeding [6-8]. Flaming is a weed control method that uses thermal energy to control weeds by heating plant tissue rather than burning it [9]. Propane burners are commonly employed as a heat source to generate very high temperature flames (up to $1900{ }^{\circ} \mathrm{C}$ ), which in turn rapidly raises the temperature of exposed of plant tissues [10]. As a consequence, plant cell walls rupture, cell juice is spilled, and cells become dehydrated; thus, the overall plant's competitive ability is drastically reduced [11].

Flaming is nonselective in nature and its selective application in row crops represents the major challenge of implementing any flame-weeding technology in a crop production system. Biological factors are generally considered to be the most important and are reflected in plants' ability to tolerate heat and recover after flaming treatment. Selection of flaming treatments also depends on optimization of equipment design parameters, such as burner type, burner configuration (number, gas flow, height, angle, and orientation), and usage of open or covered flames [12,13]. In agronomic row crops, cross flaming or parallel flaming are the two most prevalent equipment designs for flaming equipment that is commercially available $[14,15]$. Both designs typically have burners angled down at $25^{\circ}-45^{\circ}$ and positioned 10-25 cm on each side of the crop row, however, they differ in burner orientations. The back-flaming design is a variation of cross flaming with an orientation of burners toward the back. During back flaming, two flames collide at one point within the crop row, allowing concentrated heat for better weed killing efficiency. Parallel-flaming design has an open or closed (hooded) burner that is oriented parallel to the traveling direction. During parallel-flaming treatment, a high-velocity stream of intense heat is directed onto the weeds on either side of the crop row, providing either complete or partial treatment coverage of inter-row space. In this setup, flaming hoods are often employed to protect the crop canopy from flame injury [13], creating a more predictable and more easily controlled symmetrical temperature profile [16]. Clearly, cross-, back-, and parallel-equipment designs define the potential for crop injury from the flaming treatment due to the different extent of heat distribution within the crop rows. Therefore, more research is needed to evaluate temperature gradients around crop plants (at different heights of the crop canopy and distance from the soil surface).

The primary objective of this study is to describe patterns of within-row flame temperature distributions of cross-, back- and parallel-burner orientation for a newly designed flame cultivator in field conditions, and to discuss its implications on selective flaming applications in soybeans.

\section{Materials and Methods}

\subsection{Design of the Flame Cultivator}

The prototype flame-cultivator machine for controlling weeds by flaming and cultivation treatment in a single pass was constructed by modifying a four-row, inter-row field cultivator connected on a John Deere $6920 \mathrm{~S}$ tractor equipped with digital speed control (Figure 1A). The original field cultivator had five inter-row units (for four rows of crop) carried by gangs (J) with a set of tools that work between rows spaced $0.75 \mathrm{~m}$ apart and mounted on the $3 \mathrm{~m}$-wide main toolbar $(\mathrm{H})$ (Figure 1). Each inter-row unit consisted of three main parts: (L) gauge wheel, to aid in guidance of the machine while in operation; (I) cushion spring, to help amortize the machine during operation; and between each row there were two wings $(\mathrm{O})$ and one sweep $(\mathrm{N})$ arranged in an equilateral triangle and fitted with a $0.5 \mathrm{~m}$-wide sweep, a working element of the cultivator (Figure 1). This design enabled mechanical removal of weeds in inter-row space as described by Bowman [17]. 


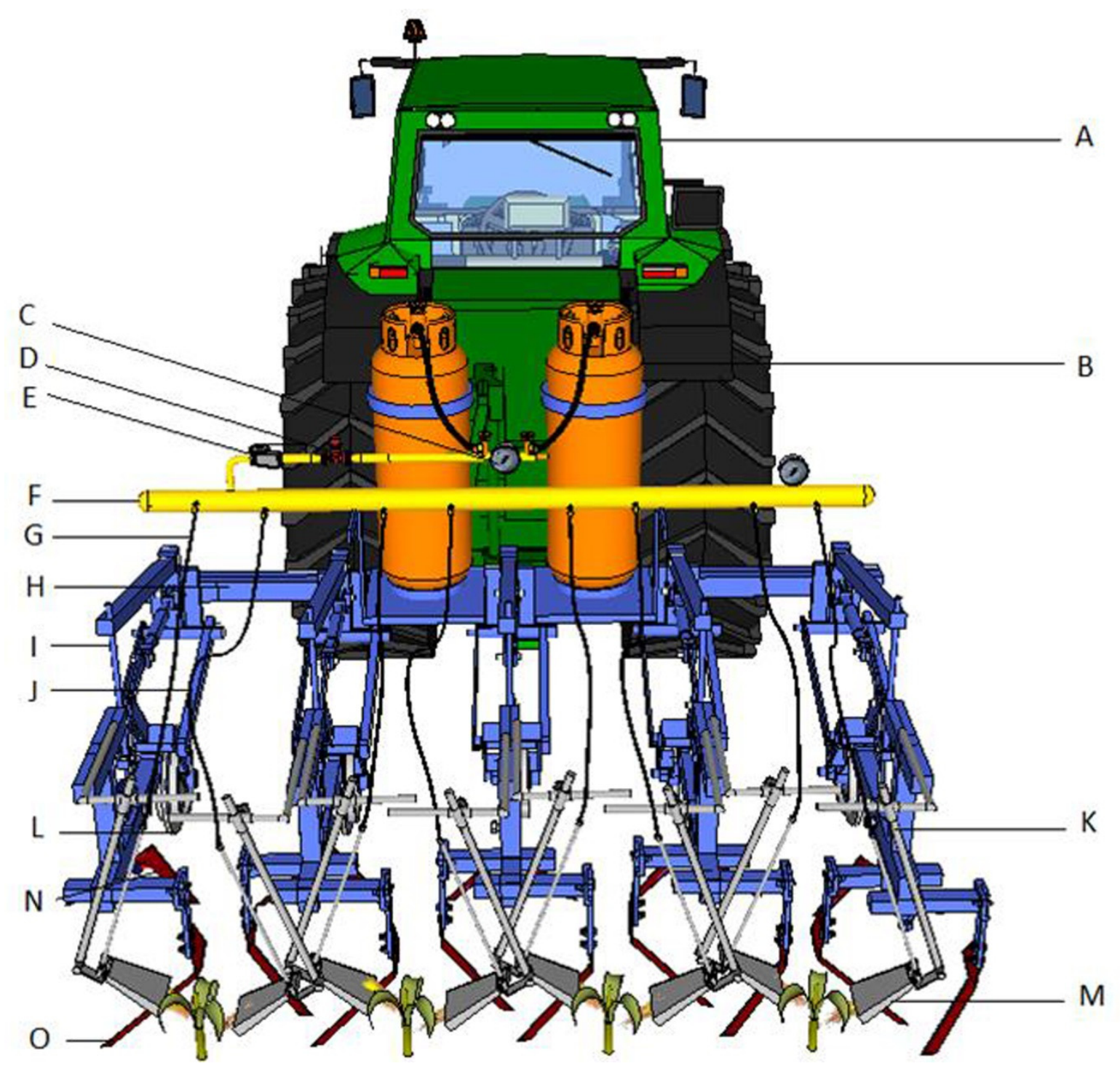

Figure 1. Flame-cultivator machine (A-tractor John Deere 6920S, B-propane tank, C-manometer, D-pressure regulator, E-flowmeter, F-gas installations, G-gas hose, $\mathrm{H}$-main toolbar, I-cushion spring, J-gang, K-torch bar, L-gauge wheel, M-burner, N-sweep, O-wing).

Flaming elements, including propane supply tanks, hoses and fittings, and burners, were added to the existing frame of a four-row cultivator to enable thermal control of weeds by flaming in an intrarow (within row) space of $0.25 \mathrm{~m}$. In this way, weeds were suppressed in the row of the crop with propane burners (M), while between the rows, weeds were mechanically suppressed by sweeps $(\mathrm{N})$ and wings $(\mathrm{O})$. Two $35 \mathrm{~kg}$ supply tanks of propane (B) were mounted on the top and in the middle of the main cultivator beam (Figure 1). The supply network consisted of two gas hoses $(\mathrm{G})$ that connected each propane tank to a regulatory gas pipe equipped with a manometer (C), pressure regulator $(D)$, flowmeter $(E)$, main gas tube $(F)$, and eight burner hoses $(G)$ supplying propane gas to eight burners (M), each carried by a torch bar (K) (Figure 1).

Custom burners had a sheet-iron burner chamber that was $15 \mathrm{~cm}$ long, $6.2 \mathrm{~cm}$ wide, and $1.6 \mathrm{~cm}$ high at the inlet, and $11.6 \mathrm{~cm}$ wide by $2.5 \mathrm{~cm}$ high at the outlet (Figure 2). The burner chamber had a $1 \mathrm{~cm}$ opening at the inlet side to allow natural air flow necessary for combustion. The burner had an additional rod (vaporizing chamber) that was passed through the middle of the burner chamber (Figure 2). Propane was injected into the burner chamber using two steel round nozzles with a $0.5 \mathrm{~mm}$ 
diameter hole. Two custom burners were placed on each side of the row and angled down $45^{\circ}$, as recommended by Storeheier [18].
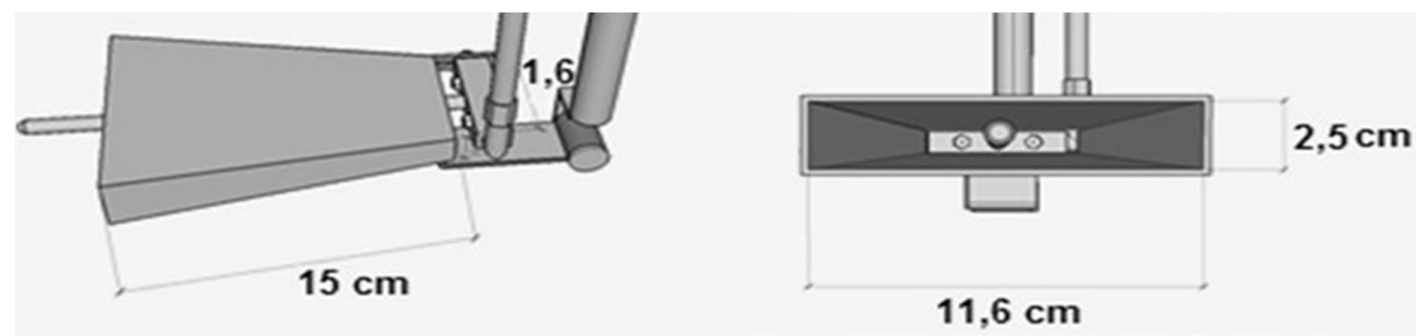

Figure 2. Burner, including specifications for the burner device used in the experiment.

\subsection{Experimental Design and Treatments}

Two separate field experiments were conducted at the Institute of Field and Vegetable Crops in Novi Sad, Serbia $\left(45^{\circ} 19^{\prime} 29^{\prime \prime} \mathrm{N}, 19^{\circ} 50^{\prime} 58^{\prime \prime} \mathrm{E}\right)$. The first experiment was set up to quantify within-row flame temperature distribution, while the second experiment served as a case study for evaluating the biological response of a crop (i.e., soybean, Glycine max (L.) Merr.) to selective flaming applications [19].

Application of flaming treatments was done using our prototype flame cultivator. Burner orientation was adjusted to either cross, back, or parallel (Figure 3) prior to application of different propane doses. The cross position was characterized by burners that were positioned at an angle of $45^{\circ}$ relative to the soil surface. Burners directed the heat towards the ground in the middle of the crop row. In this way, the flame was reflected from the ground and the temperature was decreased in the middle of the row. At the back position, the burners were directed backward in relation to the direction of the machine. Flames from the two burners confronted each other in this position and the heat was concentrated in the middle of the row. In the parallel position, the burners were positioned parallel to the row of crops. In this way, the heat of the flame was not directed towards the middle of the crop row, so it did not reach enough of the crop row area to suppress weeds.
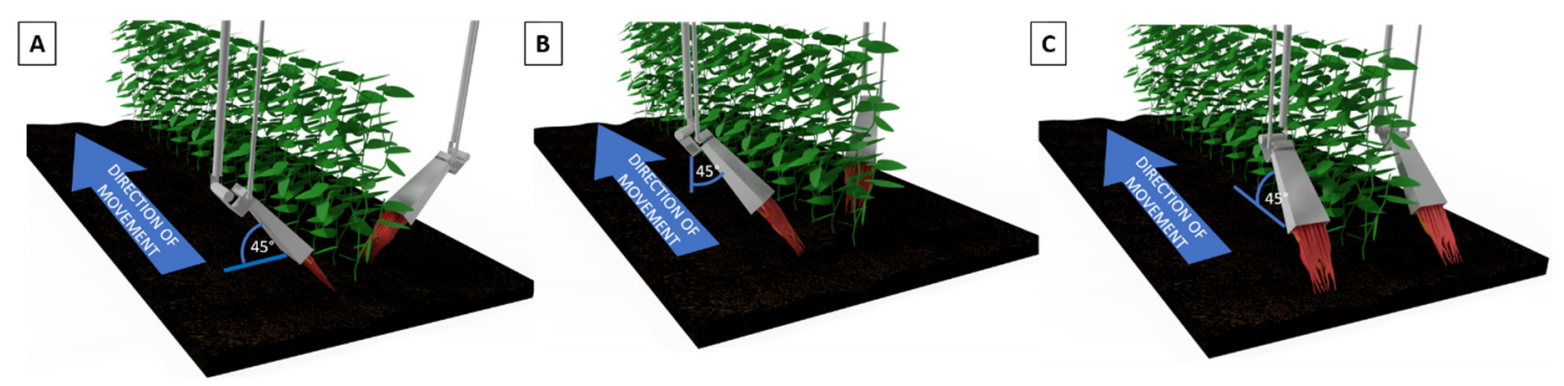

Figure 3. Schematic representation of cross (A), back (B), and parallel (C) burner orientation.

A constant pressure of 1 bar was maintained while driving speed was adjusted $(10,6.7,5,4$, $3.3,2.5$, and $2 \mathrm{~km} / \mathrm{h}$ ) to deliver propane doses of $20,30,40,50,60,80$, and $100 \mathrm{~kg} / \mathrm{ha}$, respectively. Maintaining constant pressure at 1 bar allowed for better stability of flames on the custom burner and prevented freezing of the propane tank and supply system installations that occurred at higher pressures. Flaming applications were conducted over the bare soil and under environmental conditions with wind speed not exceeding $0.2 \mathrm{~m} / \mathrm{s}$.

\subsubsection{Flame Temperature Measurements}

Flame temperature measurements were obtained by positioning type $\mathrm{K}$ thermocouples (chrome aluminum; [20,21]) at eight different canopy heights $(0,2,4,6,8,10,14$, and $18 \mathrm{~cm}$ above the soil surface). During the application of flaming treatments, the thermocouples were stationary while burners of 
the flame cultivator were allowed to flow freely on each side of the thermocouples. Continuous measurements of flame temperatures were recorded with an analog logger (Servogor 220), following the pattern of a rapid increase, peak, and rapid decrease in flame temperature. As a result, peak temperature (i.e., response variable) for each combination of propane dose and canopy height was used to describe patterns of flame temperature distribution for three burner orientations. All flaming treatments were replicated four times.

\subsubsection{Soybean Case Study}

This experimental design for a soybean case study was a split-plot with four replications. The whole-plot treatments were three burner orientations (cross, back, and parallel) and the split-plot treatments were seven propane doses $(20,30,40,50,60,80$, and $100 \mathrm{~kg} / \mathrm{ha})$. The study area was planted to soybean cultivar Sava (I maturity group) using a four-row planter with a $75 \mathrm{~cm}$ row spacing and seeding rate of 460,000 seeds/ha. All plots were kept weed-free for the entire growing season. The flaming treatments were applied to individual soybean plots $3 \mathrm{~m}$ wide by $10 \mathrm{~m}$ long when soybeans were at V3 stage (third fully elongated trifoliate).

Percent crop injury was visually assessed at 28 days after treatment (DAT) using a scale from $0 \%$ to $100 \%$, with $0 \%$ representing no injury and $100 \%$ representing complete plant death. After the visual ratings were conducted, six plants from each plot were measured for plant height, cut at ground level, and shoot dry matter was determined after drying at $70^{\circ} \mathrm{C}$ to a constant mass. Plant height reduction $(\%)$ and dry matter reduction (\%) were then calculated as a percentage of height $(69 \mathrm{~cm})$ and dry matter (67 g) of soybean plants observed in a control plot (nonflamed plants), respectively. For soybean grain harvest, $15 \mathrm{~m}^{2}$ areas of the center two rows of each plot were harvested with a Wintersteiger harvester for small plots and the yield was calculated to $13 \%$ moisture content. Soybean grain yield reduction $(\%)$ was then calculated as a percentage of grain yield observed in the control (i.e., nonflamed) plots (i.e., $3.50 \mathrm{t} / \mathrm{ha}$ ).

\subsection{Statistical Analysis}

\subsubsection{Flame Temperature Distribution-Response Surface}

We used response surface models to characterize the within-row flame temperature distributions of three burner orientations (cross, back, and parallel) as affected by the complete spectrum of interaction between two predictor variables, i.e., propane doses and canopy heights.

An a priori set of response surface models were used to fit the flame temperature data. These consisted of three generalized linear models (GLM), including first order (linear, Equation (1)), second order (quadratic, Equation (2)), and third order (cubic, Equation (3)), and a polynomial and generalized additive model (GAM, Equation (4)):

$$
\begin{gathered}
Y n=a+b_{1} D+b_{2} H, n=1 \\
Y n=a+b_{1} D+c_{1} D_{2}+b_{2} H+c_{2} \mathrm{H}_{2}, n=2 \\
Y n=a+b_{1} D+c_{1} D_{2}+d_{1} D_{3}+b_{2} H_{2}+c_{2} H_{2}+d_{2} H_{3}, n=3 \\
Y=a+s(D, H)
\end{gathered}
$$

where $Y n$ is the flame temperature response variable, $n$ is the first-, second-, or third-order polynomial model, $D$ is the propane dose (first predictor variable), $H$ is the canopy height (second predictor variable), $a$ is the intercept, $b_{1}, c_{1}$, and $d_{1}$ are the linear, quadratic, and cubic terms for $D$, respectively, $b_{2}, c_{2}$, and $d_{2}$ are the linear, quadratic, and cubic terms for $H$, respectively, and $s(D, H)$ is a smooth function allowing complete interaction between smooth terms of both predictor variables [22].

The GAM is a group of nonparametric smoothers that are more sensitive to capturing nonlinear response patterns [23]. Similar to GLMs, GAM models provide an approximated function of the 
response surface, but variation in the data is allowed to affect this function more than in the linear models. The result is a model that has more "variations" than a GLM, but is not overfitted [22].

The adequacy of a model among the pool of candidates was accessed using the information-theoretic model comparison approach, also known as Akaike's Information Criterion (AIC) [24]. In information theory, AIC represents the Kullback-Leibler distance between the model and the "truth," and is calculated as:

$$
A I C=-2 \ln (\mathrm{L})+2 \mathrm{k}
$$

where $A I C=$ Akaike's Information Criterion, $\mathrm{k}=$ number of estimated parameters in the model, and $\mathrm{ln}$ $(\mathrm{L})=\log$-likelihood function for the model. Therefore, the preferred model amongst the pool of candidates is the one with the lowest $A I C$ value. To rank the models, AIC difference $(\triangle i A I C)$ was calculated as the difference between the AIC of the best model (AICmin) and the AIC of ith model (AICi):

$$
\triangle i A I C=A I C i-A I C \min
$$

The $\triangle i A I C$ values were then rescaled to Akaike weights (Wi) using Equation (7) [24]. The Wi values sum to 1 and indicate the probability of model $i$ being the best model among the pool of candidates:

$$
\mathrm{Wi}=\frac{\exp (-0.5 \times \Delta \text { AIC } c i)}{\sum_{k=1}^{k} \exp (-0.5 \times \Delta i A I C c k)}
$$

The model with highest Wi was selected for graphical representation (contour plot) of temperature distribution for a given burner orientation. All analyses and graphical representations were performed using the open-source statistical software, $R$ version 3.1.1. [25].

\subsubsection{Soybean Case Study—Dose Response}

All measured parameters, including crop injury at 28 DAT (\%), crop height reduction at 28 DAT (\%), dry matter reduction at 28 DAT (\%), and grain yield reduction (\%), were subjected to a nonlinear regression analysis for three burner orientations and over seven propane doses using the four parameter log-logistic model (Equation (8)) [26-28], where the lower asymptote was fixed to 0 and the upper asymptote was fixed to 100 :

$$
Y=\mathrm{C}+(\mathrm{D}-\mathrm{C}) /\{1+\exp [\mathrm{B}(\log \mathrm{X}-\log \mathrm{E})]\}
$$

where $Y$ is the response (e.g., percent dry matter reduction), $\mathrm{C}$ is the lower limit, $\mathrm{D}$ is the upper limit, $\mathrm{B}$ is the slope of the line at the inflection point, $\mathrm{X}$ is the propane dose, and $\mathrm{E}$ is the dose resulting in a $50 \%$ response between the upper and lower limit (also known as the inflection point, I50 or ED50). All statistical analyses and graphs were performed with R 3.1.1. utilizing the dose-response curves statistical add-on package [25].

\section{Results}

\subsection{Flame Temperature Distribution}

The additive model had the lowest AIC corrected for small sample size (AICc) score for all three burner orientations (Table 1). There was strong evidence in favor of the additive model as compared to other models receiving very close to $100 \%$ of the total weight of all the models considered. Therefore, the additive model was selected for graphical representation of the within-row flame temperature distribution (Table 1). 
Table 1. Candidate models, number of parameters (K), and Akaike's Information Criterion corrected for small sample size (AICc), increase over the lowest AICc ( $\triangle A I C c)$, and Akaike model weight (Wi) for models we used to examine the influence of propane dose $(\mathrm{kg} / \mathrm{ha})$ and canopy height $(\mathrm{cm})$ on within-row flame temperatures for cross-, back-, and parallel-burner orientation, relative to rows of crops.

\begin{tabular}{cccccc}
\hline Burner Orientation & Candidate Models & K & AICc & Deltas & Wi \\
\hline \multirow{4}{*}{ Cross } & additive & 23 & 2563 & 0 & $1.00 \times 10^{0}$ \\
& third-order polynomial & 8 & 2592 & 29 & $5.84 \times 10^{-7}$ \\
& second-order polynomial & 6 & 2652 & 88 & $6.19 \times 10^{-20}$ \\
& first-order polynomial & 4 & 2659 & 96 & $1.66 \times 10^{-21}$ \\
\hline \multirow{5}{*}{ Back } & additive & 17 & 2279 & 0 & $9.93 \times 10^{-1}$ \\
& third-order polynomial & 8 & 2289 & 10 & $6.47 \times 10^{-1}$ \\
& second-order polynomial & 6 & 2404 & 125 & $6.19 \times 10^{-20}$ \\
& first-order polynomial & 4 & 2613 & 334 & $1.66 \times 10^{-21}$ \\
\hline \multirow{5}{*}{ Parallel } & additive & 8 & 2226 & 0 & $9.93 \times 10^{-1}$ \\
& third-order polynomial & 8 & 2235 & 10 & $7.43 \times 10^{-3}$ \\
& second-order polynomial & 6 & 2342 & 116 & $6.49 \times 10^{-26}$ \\
& first-order polynomial & 4 & 2352 & 126 & $4.56 \times 10^{-28}$ \\
\hline
\end{tabular}

\subsection{Within-Row Flame Temperature Patterns}

The following are the burner orientation and directions for interpreting the flame temperature patterns, assessed by a visual inspection of contour plots (Figure 4), using two reference points:

1. $100^{\circ} \mathrm{C}$ temperature (i.e., lethal temperature), defined as a temperature sufficient to cause lethal effect on most plants [29]. It provides a range of propane doses and canopy heights where lethal effect is observed.

2. $50 \mathrm{~kg} / \mathrm{ha}$ (i.e., lethal dose), defined as a propane dose sufficient to provide $90 \%$ control of most grass and broadleaf weeds commonly found in temperate cropping systems [30]. It describes changes in flame temperatures throughout the canopy at propane doses most commonly used in cropping systems.

Overall, flame temperatures were the highest at lower canopy height $(0-8 \mathrm{~cm})$ and higher propane doses $(>50 \mathrm{~kg} / \mathrm{ha})$, and decreased with increasing canopy height $(>8 \mathrm{~cm})$ and decrease in propane dose $(<50 \mathrm{~kg} / \mathrm{ha})$. Among the three burner orientations, back flaming resulted in the overall highest within-row flame temperatures $\left(29-269^{\circ} \mathrm{C}\right)$, followed by cross flaming $\left(33-234^{\circ} \mathrm{C}\right)$, and parallel flaming, which had the lowest overall within-row flame temperatures $\left(25-155^{\circ} \mathrm{C}\right)$ (Figure 4$)$.

Back flaming achieved $100{ }^{\circ} \mathrm{C}$ lethal temperatures and higher canopy heights than cross and parallel flaming. For example, a minimum propane dose at which $100{ }^{\circ} \mathrm{C}$ lethal temperature occurred was 27,40 , and $50 \mathrm{~kg} / \mathrm{ha}$ for back, cross, and parallel flaming, respectively (Figure 4 ). The contour line for the $100{ }^{\circ} \mathrm{C}$ lethal temperature was stretched between propane doses of $40-100 \mathrm{~kg} / \mathrm{ha}$ at $5-7 \mathrm{~cm}$ canopy heights, and remained at the $40 \mathrm{~kg} /$ ha propane dose, reducing from 5 to $0 \mathrm{~cm}$ in canopy heights. In addition, maximum canopy height at which $100^{\circ} \mathrm{C}$ occurred was 18,7 , and $5 \mathrm{~cm}$ for back, cross, and parallel flaming, respectively (Figure 4). These results suggest that adjustments of the propane dose would be necessary when changing burner orientation, especially in the back position.

Flame temperatures at a lethal dose of $50 \mathrm{~kg} / \mathrm{ha}$ were much smaller with parallel flaming, regardless of the canopy heights. For example, maximum flame temperatures at lower canopy heights $(<6 \mathrm{~cm})$ were 150,125 , and $100{ }^{\circ} \mathrm{C}$ for back, cross, and parallel flaming, respectively (Figure 4). Furthermore, flame temperatures higher in the canopy (at $18 \mathrm{~cm}$ ) were 60,30 , and $20^{\circ} \mathrm{C}$ for back, cross, and parallel flaming, respectively (Figure 4). 

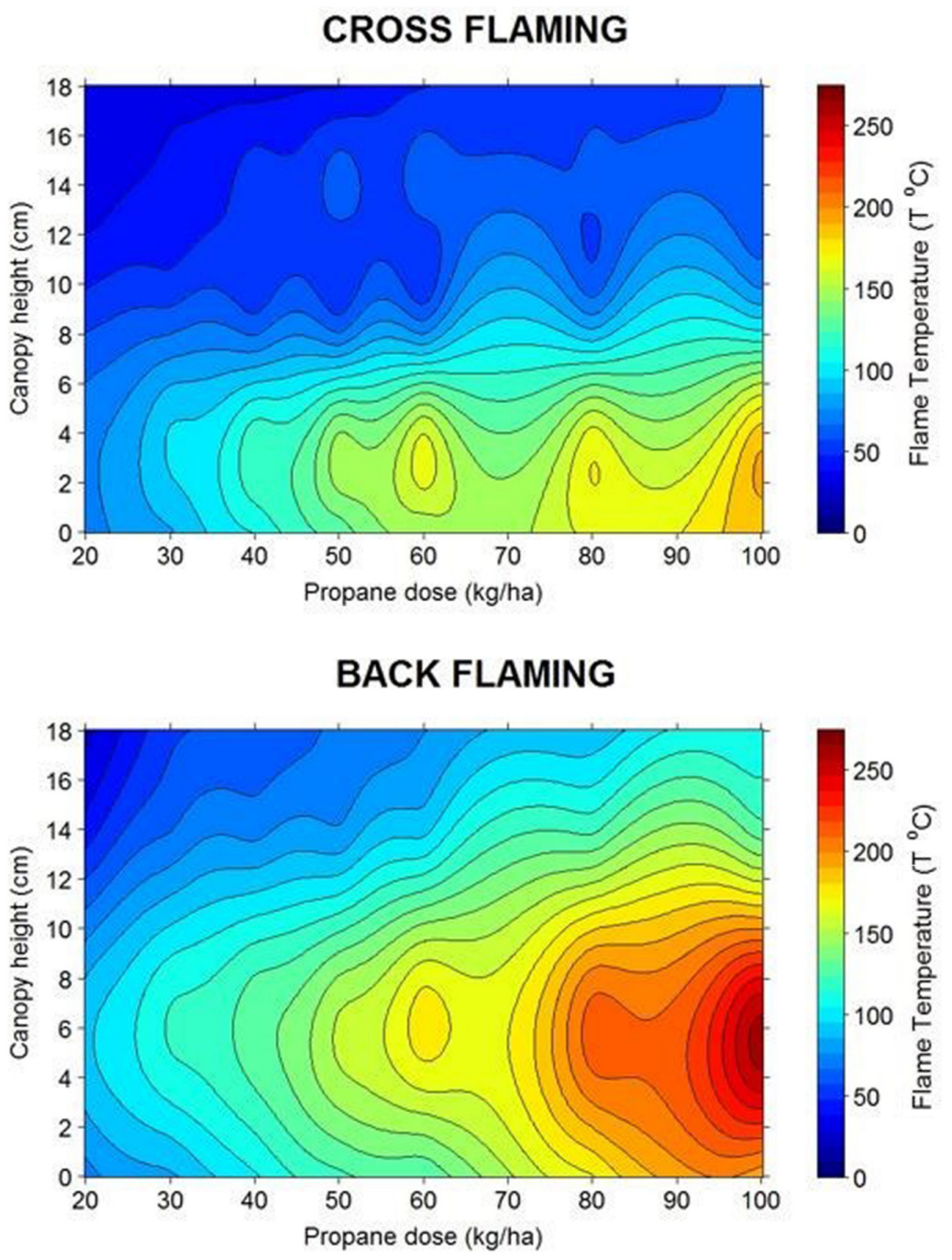

PARALLEL FLAMING

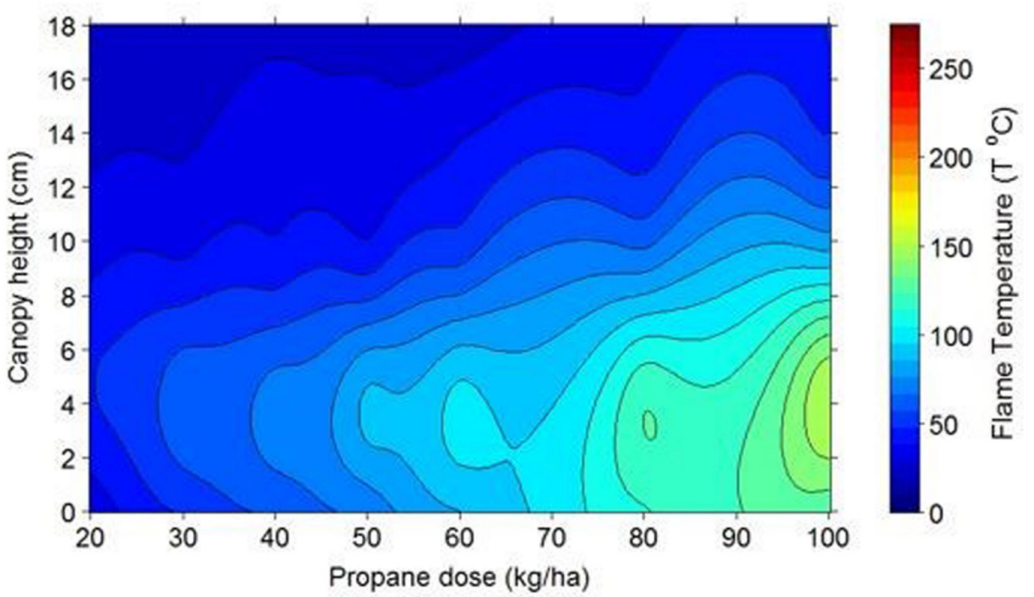

Figure 4. Within-row flame temperature distribution for cross, back, and parallel burner orientation at different propane doses $(\mathrm{kg} / \mathrm{ha})$ and canopy heights $(\mathrm{cm})$ during the field testing of the flame cultivator. 


\subsection{Soybean Case Study Results}

Flaming is nonselective to the plants, so although this measure has good efficiency for weed control, it also damages growing plants. Damage on soybean plants by flame was noticed at 1 DAT. Symptoms of damage were manifested in the form of partial to complete necrosis of the oldest leaves, which were exposed to high temperatures as a result of propane combustion. This was followed by the recovery of the plants, so that by 28 DAT there was no visible necrotic on the leaves. However, soybean plants were slower in growth and development, especially at higher doses of propane. This is indicated by crop injury, crop height reduction, dry matter reduction, and grain yield reduction (Figure 5).

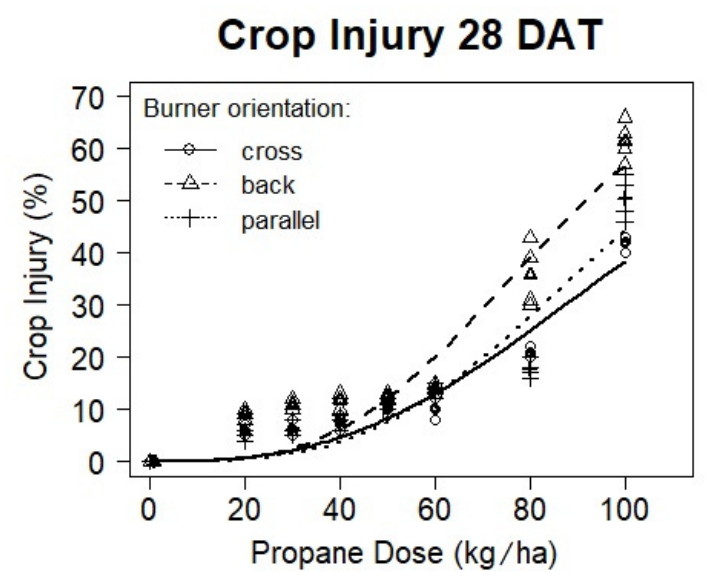

Dry Matter Reduction 28 DAT

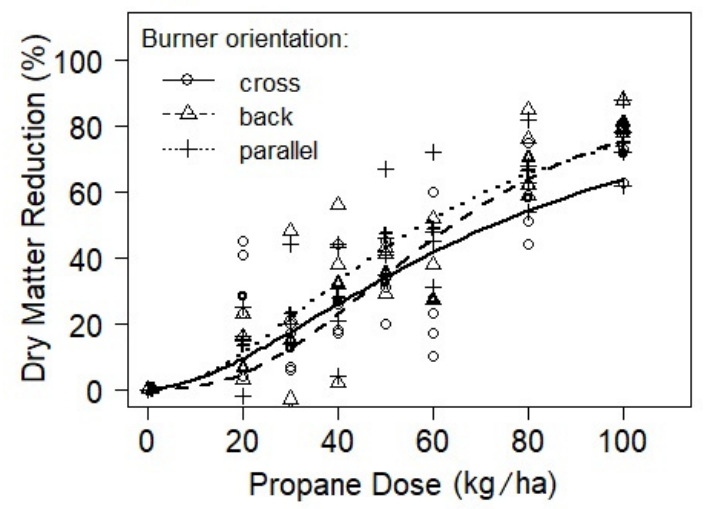

\section{Crop Height Reduction 28 DAT}

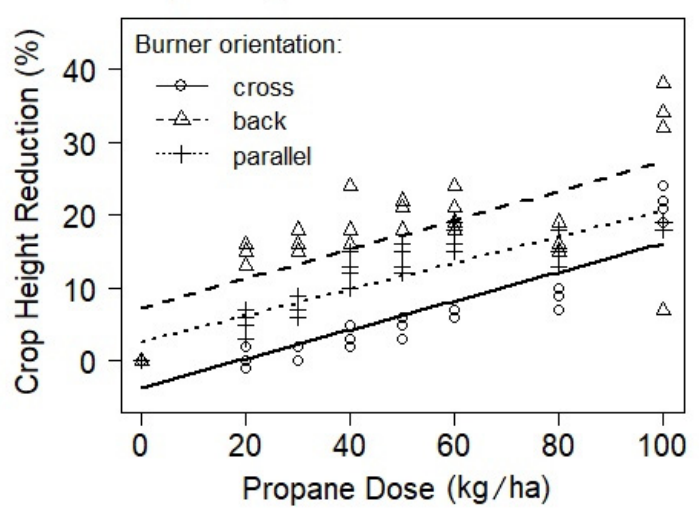

Grain Yield Reduction

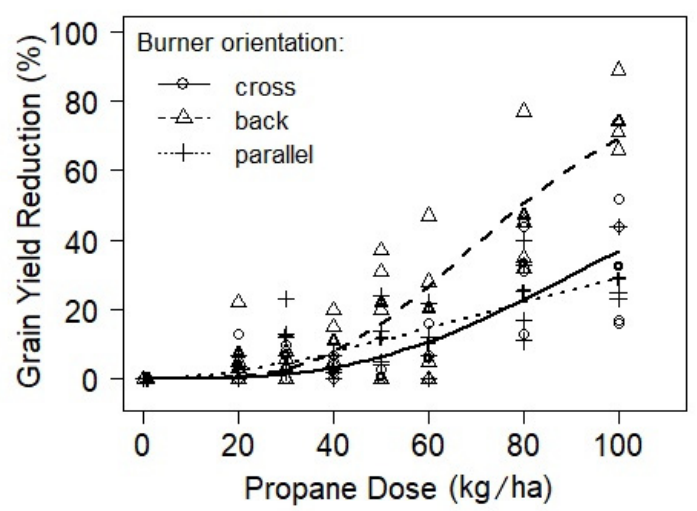

Figure 5. Soybean crop injury (\%) 28 days after treatment (DAT), crop height reduction (\%) 28 DAT, dry matter reduction (\%) 28 DAT, and grain yield reduction (\%) as affected by cross, back, and parallel burner orientation and propane doses $(0-100 \mathrm{~kg} / \mathrm{ha})$; soybeans plants were flamed at V3 growth stage.

Among the three burner orientations, back flaming appeared to have the most negative impact on the soybean crop: injury, plant height, dry matter, and grain yield, regardless of the propane dose $50 \mathrm{~kg} / \mathrm{ha}$ resulted in flame temperatures of about $125^{\circ} \mathrm{C}$ at $0-5 \mathrm{~cm}$ canopy heights, and then at an approximate rate of $+7.3^{\circ} \mathrm{C} / \mathrm{cm}$, gradually decreased from $125^{\circ} \mathrm{C}$ (Figure 5). For example, back flaming caused $4 \%$ higher soybean crop injury at $50 \mathrm{~kg} / \mathrm{ha}$ than cross and parallel flaming (Table 2, Figure 5). Similarly, there was $16 \%$ reduction in crop height at 28 DAT with back flaming, which was more than the $5 \%$ and $10 \%$ height reductions that were observed after parallel and cross flaming, respectively (Table 2, Figure 5). While dry matter reduction was similar for all burner orientations, back flaming caused $6 \%$ grain yield reduction at $50 \mathrm{~kg} / \mathrm{ha}$ (i.e., $210 \mathrm{~kg} / \mathrm{ha}$ ), which was less than $11 \%$ (i.e., $374 \mathrm{~kg} / \mathrm{ha}$ ) and $16 \%$ (i.e., $560 \mathrm{~kg} / \mathrm{ha}$ ) grain yield reduction for cross and parallel flaming, respectively (Table 2, 
Figure 5). The difference in grain yield reduction between back flaming and parallel/cross flaming only got bigger at higher propane doses (Figure 5).

Table 2. Regression parameters $( \pm \mathrm{SE}$ ) for the response of soybean crop injury (\%) 28 days after treatment (DAT), crop height reduction (\%) 28 DAT, dry matter reduction (\%) 28 DAT, and grain yield reduction (\%) as affected by cross, back, and parallel burner orientation and dose of propane (0-100 kg/ha) (Figure 5). Predicted response of all evaluated parameters at $50 \mathrm{~kg} / \mathrm{ha}$ propane dose are also included.

\begin{tabular}{|c|c|c|c|c|}
\hline \multirow{2}{*}{$\begin{array}{l}\text { Evaluated } \\
\text { Parameter }\end{array}$} & \multirow{2}{*}{$\begin{array}{c}\text { Burner } \\
\text { Orientation }\end{array}$} & \multicolumn{2}{|c|}{ Regression Parameters $( \pm$ SE) } & \multirow{2}{*}{$\begin{array}{c}\text { Predicted Response a } \\
50 \mathrm{~kg} / \mathrm{ha}(\%)\end{array}$} \\
\hline & & B & I50 & \\
\hline \multirow{3}{*}{$\begin{array}{c}\text { Crop injury (\%) } 28 \\
\text { DAT }\end{array}$} & Cross & $-2.7(0.3)$ & $118(5)$ & 8 \\
\hline & Back & $-3.2(0.4)$ & $92(3)$ & 12 \\
\hline & Parallel & $-3.3(0.5)$ & $107(4)$ & 8 \\
\hline \multirow{3}{*}{$\begin{array}{c}\text { Crop height } \\
\text { reduction }(\%) 28 \\
\text { DAT }\end{array}$} & Cross & $-3.6(1.0)$ & $0.20(0.02)$ & $5(3.45 \mathrm{~cm})$ \\
\hline & Back & $7.32(2.1)$ & $0.20(0.04)$ & $16(11.04 \mathrm{~cm})$ \\
\hline & Parallel & $2.66(0.9)$ & $0.18(0.02)$ & $10(69.00 \mathrm{~cm})$ \\
\hline \multirow{3}{*}{$\begin{array}{c}\text { Dry matter } \\
\text { reduction (\%) } 28 \\
\text { DAT }\end{array}$} & Cross & $-1.8(0.4)$ & $73(6)$ & 32 \\
\hline & Back & $-2.6(0.5)$ & $64(4)$ & 32 \\
\hline & Parallel & $-1.9(0.3)$ & $57(7)$ & 40 \\
\hline \multirow{3}{*}{$\begin{array}{c}\text { Grain Yield } \\
\text { Reduction (\%) }\end{array}$} & cross & $-3.1(0.7)$ & $119(11)$ & $6(210 \mathrm{~kg} / \mathrm{ha})$ \\
\hline & back & $-3.6(0.6)$ & $80(4)$ & $16(560 \mathrm{~kg} / \mathrm{ha})$ \\
\hline & parallel & $-1.8(0.5)$ & $136(23)$ & 11 (374 kg/ha) \\
\hline
\end{tabular}

Abbreviations for the four-parameter log-logistic model: B, the slope of the line at the inflection point; I50, the dose of propane resulting in a $50 \%$ response between the upper and lower limit.

Parallel flaming and cross flaming had similar impact on soybean plants despite much lower within-row flame temperatures observed with parallel flaming. In this study, flame temperature was measured up to $30^{\circ} \mathrm{C}$ at $13-18 \mathrm{~cm}$ canopy heights (Figure 4) which is not enough for controlling weeds. Although increase in flame temperatures above $18 \mathrm{~cm}$ is very unlikely, orienting burners parallel to the crop row increases the exposure time of soybean tissue to the flames and consequently increases potential for crop injury.

\section{Discussion}

\subsection{Importance of Flame Temperature Measurements}

Back flaming generated much higher within-row flame temperatures than parallel and cross flaming, causing higher crop injury, dry matter reduction, and yield penalties of soybeans flamed at V3 growth stage. Other research also found that quantifying flame temperature changes on the leaf surface for a particular equipment design (e.g., burner orientations) was a critical factor in understanding the selectivity of flaming application in a given cropping system [29-31]. Various types of burners are able to generate stationary flame temperatures from 1900 to $2600{ }^{\circ} \mathrm{C}$, depending on specifications for gas-flow rate, nozzle size, tube length, and operating pressure [32,33]. Under field conditions, however, flame temperature on the leaf surface is much lower, as exposure time is reduced by changing vehicle speed, burner angle, and/or burner orientation [34].

\subsection{Designing Selective Flaming Equipment}

All three burner orientations had maximum within-row flame temperatures at the lower canopy heights $(<6 \mathrm{~cm})$. Flame temperatures gradually decreased higher in the canopy $(6-18 \mathrm{~cm})$, reaching its minimum at $18 \mathrm{~cm}$ where flame temperatures were reduced by $74 \%, 64 \%$, and $71 \%$ for cross, back, and parallel flaming, respectively. Others also observed a decrease in flame temperatures as flames hit the soil surface and continue to decrease with increasing canopy height [35,36]. Seifert and Snipes [36] reported a $25 \%-30 \%$ decrease in flame temperatures between the soil surface and $10 \mathrm{~cm}$ of canopy 
height, and a $35 \%-45 \%$ decrease in flame temperatures between 10 and $20 \mathrm{~cm}$ of canopy height. A better understanding of flame temperature patterns can assist in designing other parts of flaming equipment that can be utilized in a complementary manner to increase the overall machine performance [13]. For example, shields may be employed during parallel flaming to increase propane-use efficiency (by as much as $50 \%$ ) and to protect the crop from the intense heat [13]. Likewise, during the cross flaming, the heat is distributed from the base of the plant in the outward and upwards directions, as well as along the plant row, selectively killing the weeds within the crop row; thereby suggesting that the open burners are the preferred design when using a cross-burner orientation [37].

\subsection{Selective Flaming in Soybeans}

Flame temperature patterns varied greatly between cross, back, and parallel flaming, suggesting that optimal burner orientation should be selected after careful consideration of its interactions with biological factors that affect selectivity of flaming. In this soybean case study, cross flaming caused similar crop injury and higher yield reduction in soybean than parallel flaming, despite the higher flame temperatures, particularly in the lower canopy $(<6 \mathrm{~cm})$. Cross-burner orientation shortened the time soybean plants were exposed to the flames while increasing the within-row flame temperatures (Figure 4). These results suggest that cross flaming may be the optimal burner orientation when flaming taller broadleaf crops (e.g., soybean or sunflower) at later growth stages. Having the growing point of the crop positioned above the flames allows cross flaming to effectively control the weeds within the crop row without significantly damaging the crop. More research, however, is needed to evaluate the effects of flames on the adjacent crop row during cross-flaming treatment.

During the parallel-flaming treatment, a high-velocity stream of heat strikes the ground surface, and a fan-shaped pattern of heat distribution deflects a small portion of the heat into the crop row [38]. Flame temperature patterns observed in our study support these findings, as parallel flaming had a lower maximum temperature $\left(150{ }^{\circ} \mathrm{C}\right)$ compared to cross and back flaming $\left(200\right.$ and $270{ }^{\circ} \mathrm{C}$, respectively). Nevertheless, without employing shields to protect the upper portion of the crop canopy from heat, parallel flaming can cause significant damage to broadleaf crops that are later in their development [13]. In this study, soybean yield reduction with parallel flaming was higher (11\%) than with cross flaming (6\%), despite the lower within-row flame temperature profile. Ulloa et al. [39] reported that parallel flaming may be the preferred burner orientation when flaming smaller soybean crops $(<6 \mathrm{~cm}$ tall), as it exposes sensitive plants to lower flame temperatures and decreases the potential for crop injury. In addition, Stephenson [38] reported that turning the burners parallel to the crop row was beneficial during the early flaming treatments in cotton, when plants were $10-15 \mathrm{~cm}$ tall.

\subsection{Selective Flaming in Other Crops}

Quantifying flame temperature measurements under field conditions also allows us to make inferences on the potential impact of equipment design parameters (e.g., burner orientation) for selective flaming applications in other crops. For example, back flaming may be the preferred burner orientation when flaming V6 field corn $(\sim 25 \mathrm{~cm}$ tall) that has a lot of weeds within the row because: (1) back flaming generated lethal flame temperatures $\left(100{ }^{\circ} \mathrm{C}\right)$ at lower propane dose $(27 \mathrm{~kg} / \mathrm{ha})$ compared to cross and parallel flaming (40 and $50 \mathrm{~kg} / \mathrm{ha}$ ), thus, propane consumption and cost of application can be reduced; (2) corn is very tolerant at V6 stage, as its growing point is at the soil surface and well protected with several layers of leaf sheets [40]; and (3) at V6 stage weeds are typically smaller than corn and are effectively controlled using a $50 \mathrm{~kg} /$ ha propane dose [41]. Negative aspects of back flaming are mostly associated with the unstable temperature pattern that occurs with the collision of flames and under varying operating conditions [13]. For these reasons, the companies that provide technical support for flaming equipment have either cross or parallel burner orientation [14,15]. 


\section{Conclusions}

Variations of flame temperature pattern during cross, back, and parallel flaming suggest that optimal burner orientation depends largely on its interactions with both technical (i.e., equipment design) and biological factors (i.e., crop and weed tolerance to flaming) that affect selectivity of flaming. For these reasons, flexibility in adjusting burner orientation for a specific field situation may be an important aspect of flaming equipment design. Further research is needed to determine effects of burner orientation (and within-row flame temperatures) on tolerance of crops and weeds at different growth stages and integrating propane flaming with other nonchemical weed management strategies.

Author Contributions: Conceptualization and methodology, M.R and G.M.; software, M.K.; validation, M.U.; data curation, S.S.; writing—original draft preparation, M.R. and S.S.; writing—review and editing, G.M. and K.P.; supervision, S.V. All authors have read and agreed to the published version of the manuscript.

Funding: This study results from the project TR-31073 "Improving maize and sorghum production under stress" funded by the Ministry of Education, Science and Technological Development of the Republic of Serbia.

Conflicts of Interest: The authors declare no conflict of interest.

\section{References}

1. Milberg, P.; Hallgren, E. Yield loss due to weeds in cereals and its large-scale variability in Sweden. Field Crops Res. 2004, 86, 199-209. [CrossRef]

2. Kruidhof, H.M.; Bastiaans, L.; Kropff, M.J. Ecological weed management by cover cropping: Effects on weed growth in autumn and weed establishment in spring. Weed Res. 2008, 48, 492-502. [CrossRef]

3. Sumption, P.; Firth, C.; Davies, G. Observation on agronomic challenges during conversion to organic field vegetable production. In Proceedings of the BGS/AAB/COR Conference: Organic Farming: Science and Practice of Profitable Livestock and Cropping, Newport, Shropshire, UK, 20-22 April 2004; Hopkins, A., Ed.; UK British Grassland Society, Harper Adams University College. pp. 176-179.

4. Liebman, M.; Davis, A.S. Managing Weeds in Organic Farming Systems: An Ecological Approach. In Organic Farming: The Ecological System; Agronomy Monograph 54; Francis, C., Ed.; American Society of Agronomy, Crop Science Society of America, Soil Science Society of America: Madison, WI, USA, 2010; pp. 173-196.

5. Gunsolus, J. Delayed Planting, Crop Rotation Keys to Weed Control in Organic Corn, Soybeans; Ag News Wire-University of Minnesota Extension: St. Paul, MN, USA, 2011; Available online: http://blog.lib.umn.edu/umnext/news/2011/06/delayed-planting-crop-rotation-keys-to-weed-controlin-organic-corn-soybeans.php (accessed on 17 November 2019).

6. Nemming, A. Costs of flame cultivation. Acta Hort. 1994, 372, 205-212. [CrossRef]

7. Knezevic, S.Z.; Ulloa, S. Potential new tool for weed control in organically grown agronomic crops. J. Agric. Sci. 2007, 52, 95-104. [CrossRef]

8. Wszelaki, A.L.; Doohan, D.J.; Alexandrou, A. Weed control and crop quality in cabbage (Brassica oleracea (capitata group)) and tomato (Lycopersicon lycopersicum) using a propane flamer. Crop Prot. 2007, 26, 134-144. [CrossRef]

9. Leroux, G.D.; Douheret, J.; Lanouette, M. Flame weeding in corn. In Physical Control Methods in Plant Protection; Vincent, C., Panneton, B., Fleurat Lessard, F., Eds.; Springer-Verlag: Berlin/Heidelberg, Germany, 2001; pp. 47-60.

10. Ascard, J. Flame weeding: Effects of burner angle on weed control and temperature patterns. Acta Agric. Scand. B. Plant Soil Sci. 1998, 48, 248-254. [CrossRef]

11. Holekamp, E.R. Weed Control by Flame Cultivation. Prog. Agric. Ariz 1954, 6, 4.

12. Parish, S. A Review of Non-Chemical Weed Control Techniques. Biol. Agric. Hortic. 1990, 7, 117-137. [CrossRef]

13. Ascard, J. Thermal Weed Control by Flaming. Ph.D. Thesis, Department of Agricultural Engineering, Swedish University of Agricultural Sciences, Alnarp, Sweden, 1995.

14. Stepanovic, S.V.; Datta, A.; Neilson, B.; Bruening, C.; Shapiro, C.A.; Gogos, G.; Knezevic, S.Z. Effectiveness of flame weeding and cultivation for weed control in organic maize. Biol. Agric. Hortic. 2015, 32, 47-62. [CrossRef] 
15. Stepanovic, S.V.; Datta, A.; Neilson, B.; Bruening, C.; Shapiro, C.A.; Gogos, G.; Knezevic, S.Z. The effectiveness of flame weeding and cultivation on weed control, yield, and yield components of organic soybean as influenced by manure application. Renew. Agric. Food Syst. 2016, 31, 288-299. [CrossRef]

16. Neilson, B. The Integration of Propane Flaming and Mechanical Cultivation for Effective Weed Control in Agriculture. Master's Thesis, The University of Nebraska-Lincoln, Department of Mechanical and Materials Engineering, Lincoln, NE, USA, 2012.

17. Bowman, G. (Ed.) Steel in the Field: A Farmer's Guide to Weed Management Tools; Sustainable Agriculture Network: Beltsville, MD, USA, 2002.

18. Storeheier, K.J. Basic investigations into flaming for weed control. Acta Hort. 1994, 372, 195-204. [CrossRef]

19. Rajković, M.; Malidža, G.; Gvozdenović, Đ.; Vasić, M.; Gvozdanović-Varga, J. Susceptibility of bean and pepper to flame weeding. Acta Herbol. 2011, 19, 67-76.

20. Childs, P.R.N.; Greenwood, J.R.; Long, C.A. Review of temperature measurement. Rev. Sci. Instrum. 2000, 71, 2959-2978. [CrossRef]

21. Childs, P.R.N. Practical Temperature Measurement; Butterworth-Heinemann: Oxford, UK, 2001.

22. Van der Burg, M.; Powell, L.A.; Tyre, A.J. Finding the smoothest path to success: Model complexity and the consideration of nonlinear patterns in nest-survival data. Condor 2010, 112, 421-431. [CrossRef]

23. Wood, S.N.; Augustine, N.H. GAMs with integrated model selection using penalized regression splines and applications to environmental modelling. Ecol. Model. 2002, 157, 157-177. [CrossRef]

24. Burnham, K.P.; Anderson, D.R. Model Selection and Multimodel Inference: A Practical Information-Theoretic Approach; Springer Science and Business Media: New York, NY, USA, 2002.

25. R Core Team. R: A Language and Environment for Statistical Computing; R Foundation for Statistical Computing: Vienna, Austria, 2014; Available online: http://www.R-project.org (accessed on 19 November 2019).

26. Ritz, C.; Streibig, J.C. Bioassay analysis using R. J. Stat Softw. 2005, 12, 1-22. [CrossRef]

27. Knezevic, S.Z.; Streibig, J.C.; Ritz, C. Utilizing R software package for dose-response studies: The concept and data analysis. Weed Technol. 2007, 21, 840-848. [CrossRef]

28. Ritz, C.; Baty, F.; Streibig, J.C.; Gerhard, D. Dose-response analysis using R. PLoS ONE 2015, 10, e0146021. [CrossRef]

29. Vester, J. Flame cultivation for weed control-2 years' results. Proceedings of a Meeting of the EC Experts' Group, Weed Control in Vegetable Production, Commission of the European Communities Directorate-General Agriculture in collaboration with Landesanstalt Tür Pflanzenschutz Federal State of Baden-Württemberg, Stuttgart, Germany, 28-31 October 1986; pp. 153-167.

30. Knezevic, S.Z.; Datta, A.; Bruening, C.; Gogos, G.; Stepanovic, S.; Neilson, B.; Nedeljkovic, D. Propane-Fueled Flame Weeding in Corn, Soybean, and Sunflower; University of Nebraska: Lincoln, NE, USA, 2012; pp. 1-32.

31. Laguë, C.; Gill, J.; Péloquin, G. Engineering performances of propane flamers used for weed, insect pest, and plant disease control. Appl. Eng. Agric. 1997, 13, 7-16. [CrossRef]

32. Ascard, J. Comparison of flaming and infrared radiation techniques for thermal weed control. Weed Res. 1998, 38, 69-76. [CrossRef]

33. Carter, L.M.; Colwick, R.F.; Tavernetti, J.R. Evaluating flame-burner design for weed control in cotton. Trans. Amer. Soc. Agric. Eng. 1960, 3, 125-127. [CrossRef]

34. Chilcote, D.O.; Youngberg, H.W. Propane flamer burning of grass seed field stubble. Agron. Crop Sci. 1975, 3, 1-5.

35. Bruening, C.A. Development of Propane Flaming Equipment for Thermal Weed Control in Agronomic Crops. Master's Thesis, University of Nebraska, Lincoln, NE, USA, 2009.

36. Seifert, S.; Snipes, C.E. Influence of flame cultivation on mortality of cotton (Gossypium hirsutum) pests and beneficial insects. Weed Technol. 1996, 10, 544-549. [CrossRef]

37. Anderson, J. Experimental trials and modeling of hydrogen and propane burners for use in selective flaming. Biol. Agric. Hortic. 1997, 14, 207-219. [CrossRef]

38. Stephenson, K.O. Mechanized Weed Control in Cotton. Arkanses Agricultural Experiment. Arcansas Farm Res. 1962, 10, 3 .

39. Ulloa, S.M.; Datta, A.; Malidza, G.; Leskovsek, R.; Knezevic, S.Z. Yield and yield components of soybean (Glycine $\max$ (L.) Merr.) are influenced by the timing of broadcast flaming. Field Crop Res. 2010, 119, 348-354. [CrossRef] 
40. Ulloa, S.M.; Datta, A.; Bruening, C.; Neilson, B.; Miller, J.; Gogos, G.; Knezevic, S.Z. Maize response to broadcast flaming at different growth stages: Effects on growth, yield and yield components. Eur. J. Agron. 2011, 34, 10-19. [CrossRef]

41. Ulloa, S.M.; Datta, A.; Knezevic, S.Z. Growth stage-influenced differential response of foxtail and pigweed species to broadcast flaming. Weed Technol. 2010, 24, 319-325. [CrossRef] 